\title{
Bacteriocin: A potent therapeutic weapon used as an alternative to antibiotics
}

Received: 31 August, 2020

Accepted: 12 September, 2020

Published: 14 September, 2020

*Corresponding author: Vidya Chauhan, PhD Researcher, Department of Microbiology, Shri Guru Ram Rai University, Dehradun-248001 (Uttarakhand), India, E-mail: chauhanvid127@gmail.com

Keywords: Bacteriocin; Antibiotics; Antimicrobial proteins

https://www.peertechz.com

\author{
Vidya Chauhan* \\ PhD, Researcher, Department of Microbiology, Shri Guru Ram Rai University, Dehradun-248001 \\ (Uttarakhand) India
}

Check for updates

\begin{abstract}
Aim: Conventional antibiotics are easily accessible for the treatment of various health ailments. Excessive consumption of these drugs escalates serious bacterial infections. There is need to combat with this threat with effective alternatives. Bacteriocin is one such option. The aim of this review is to highlight classification, mode of action and application of bacteriocin.
\end{abstract}

Method: In the present study the literature was collected from Pubmed, Scopus, and Google Scholar.

\section{Introduction}

Bacteriocin has proved its potential as an alternative therapeutic molecule. The discovery of bacteriocin has been a miracle to combat Antibiotic Resistance including both multidrug-resistant and chronic bacterial infections. They are ribosomally synthesised Anti-Microbial Protein (AMP), produced by bacteria [1,2]. Many species of bacteria develop this antimicrobial defence for self-preservation and competitive advantage. In comparison to antibiotics bacteriocin are sensitive to proteases and being undisruptive for human consumption [3]. Bacteriocins are small cationic (30-60 amino acids), membrane-permeabilizing peptides produced by Grampositive (small- 2-6kDa)/negative (large- $>10 \mathrm{kDa}<20 \mathrm{kDa}$ ) bacterial species. Bacteriocins of Gram-negative bacteria are usually released through cell lysis often dependent on SOS regulation. Gram-positive bacteria follow self-regulated and dedicated transport mechanisms to release bacteriocin. These bacteriocins have a varied spectrum of activity, mode of action and biochemical properties $[4,5]$.

\section{Classification}

Among several classifications, Klaenhammer proposed first classification of bacteriocin in1993 [6]. According to data classification based on biological activity and biosynthesis mechanism of bacteriocin was given by Alvarez-Sieiro et al in 2016 [7]. They proposed three major classes: Class I (Lantibiotics- Type A, B and C) - small post-translationally modified peptides; Class II - unmodified bacteriocins (receptors seem to be proteins rather than lipids); and Class III - larger peptides ( $>10 \mathrm{kDa}$, thermo-labile), being each one subdivided into subclasses [8].

\section{Mode of action}

The mechanistic action of bacteriocin includes promotion of bactericidal and bacteriostatic effect with or without cell lysis. Thus, inhibiting cell growth resulting in deficiency of cell wall synthesis, changes in the membrane permeability or formation of pores causing the death of the target cells [9]. Such mechanism was observed by Cleveland J, et al. where Lantibiotics inhibited inhibit target cells by forming pores in the membrane, depleting the transmembrane potential $(\Delta \psi)$ and/ or the $\mathrm{pH}$ gradient, resulting in the leakage of cellular materials [10]. Some Bacteriocins targets the bacterial membrane while other Bacteriocins interfere with cells such as leuconocin S or pediocin JD and colicin E9 and inhibits essential enzymes [11]. Traditional antibiotics inactivate microbes by inhibiting and disrupting synthesis of cell wall, folate, protein, DNA transcription and replication; functioning of cell membrane. Bacteriocins on the other hand along with the above-mentioned modes of action forms septum to inactivate bacteria [12]. 


\section{Application}

Being non-pathogenic and harmless these Bacteriocins are considered to be a great medication for human body. Use of antibiotics on the loss of these bacteria can result the invasion in human body by some pathogenic bacteria. Bacteriocins produced by LAB are used as clinical drugs or as food preservatives [13]. Some pharmaceutical applications of bacteriocin are to control Gram negative bacteria by using microcin [14].

Malignancy and AMR pathogenic infections has increased mortality rate, resulting in global health crisis. Duration and severity of morbidity increases when it comes to the immunity of oncology patients [15]. Biocompatibility, biodegradablity and non-immunogenic nature of Bacteriocins makes it most suitable for therapeutic application [16]. In-vitro application of bacteriocins has shown therapeutic anticancer-activity against proliferation of unscheduled and unregulated tumour cell lines [17].

Due to overexploitation of antibiotics, human population is heading towards disaster, so scientists are focusing in finding new alternative. Bacteriocin show potential in this context. Bacteriocins can be used for prevention of infections, to fight against antibiotic resistance and treatment owing to their diversity and abundance. Much more research is required towards development of novel effective bacteriocins which successfully target complex bacterial systems such as cell membranes.

\section{References}

1. Ye R, Xu H, Wan C, Peng S, Wang L, et al. (2013) Antibacterial activity and mechanism of action of $\varepsilon$-poly--lysine. Biochem Biophys Res Commun 439: 148-153. Link: https://bit.ly/3kfORIO

2. Hiemstra PS, Zaat SAJ editors (2013) Antimicrobial Peptides and Innate Immunity. Progress in Inflammation Research. Springer Basel. Link: https://bit.ly/3ml6Mj5

3. Imran S (2016) Bacteriocin: An Alternative to Antibiotics. World Journal of Pharmaceutical Research 5: 467-477. Link: https://bit.ly/2ZCfUWZ

4. Ghodhbane H, Elaidi S, Sabatier JM, Achour S, Benhmida J, et al. (2015) Bacteriocins active against multi-resistant gram-negative bacteria implicated in nosocomial infections. Infect Disord Drug Targets 15: 2-12. Link: https://bit.ly/3hq13VD

5. Riley MA, Wertz JE (2002) Bacteriocins: evolution, ecology, and application. Annu Rev Microbiol 56: 117-137. Link: https://bit.ly/2DXkWFU

6. Hugenholtz J (1993) Citrate metabolism in lactic acid bacteria. FEMS Microbiology Reviews 12: 165-178. Link: https://bit.ly/3hsm4iB

7. Alvarez-Sieiro P, Montalbán-López M, Mu D, Kuipers OP (2016) Bacteriocins of lactic acid bacteria: extending the family. Appl Microbiol Biotechnol 100: 2939-2951. Link: https://bit.ly/35zqtxK

8. Holtsmark I, Eijsink VG, Brurberg MB (2008) Bacteriocins from plant pathogenic bacteria. FEMS Microbiology Letters 280: 1-7. Link: https://bit.ly/3mfHB1w
9. da Silva Sabo S, Vitolo M, González JMD, de Souza Oliveira RP (2014) Overview of Lactobacillus plantarum as a promising bacteriocin producer among lactic acid bacteria. Food Research International 64: 527-536. Link: https://bit.ly/2RnBHx7

10. Cleveland J, Montville TJ, Nes IF, Chikindas ML (2001) Bacteriocins: safe, natural antimicrobials for food preservation. Int $J$ Food Microbiol 71: 1-20. Link: https://bit.ly/2RqvXTc

11. Pommer AJ, Wallis R, Moore GR, James R, Kleanthous C (1998) Enzymologica characterization of the nuclease domain from the bacterial toxin colicin E9 from Escherichia coli. Biochemical Journal 334: 387-392. Link: https://bit.ly/3itQNNy

12. Majeed H, Lampert A, Ghazaryan L, Gillor O (2013) The weak shall inherit: bacteriocin-mediated interactions in bacterial populations. PloS one 8 e63837. Link: https://bit.ly/2FC2MtD

13. Acuña L, Picariello G, Sesma F, Morero RD, Bellomio A (2012) A new hybrid bacteriocin, Ent35-MccV, displays antimicrobial activity against pathogenic Gram-positive and Gram-negative bacteria. FEBS Open Bio 2: 12-19. Link: https://bit.ly/3bT6WcX

14. Duquesne S, Destoumieux-Garzón D, Peduzzi J, Rebuffat S (2007) Microcins, gene-encoded antibacterial peptides from enterobacteria. Nat Prod Rep 24: 708-734. Link: https://bit.ly/35A1uKY

15. Rodrigues G, Silva GGO, Buccini DF, Duque HM, Dias SC, et al. (2019) Bacterial proteinaceous compounds with multiple activities toward cancers and microbial infection. Front. Microbiol 10. Link: https://bit.ly/3bSwWFi

16. Naveen SV, Kalaivani K (2018) Cancer stem cells and evolving novel therapies: a paradigm shift. Stem Cell Investig 5: 4. Link: https://bit.ly/35AITzW

17. Yang SC, Lin CH, Sung CT, Fang JY (2014) Antibacterial activities of bacteriocins: application in foods and pharmaceuticals. Front Microbiol 5 241. Link: https://bit.ly/3mkWMq8

Discover a bigger Impact and Visibility of your article publication with Peertechz Publications

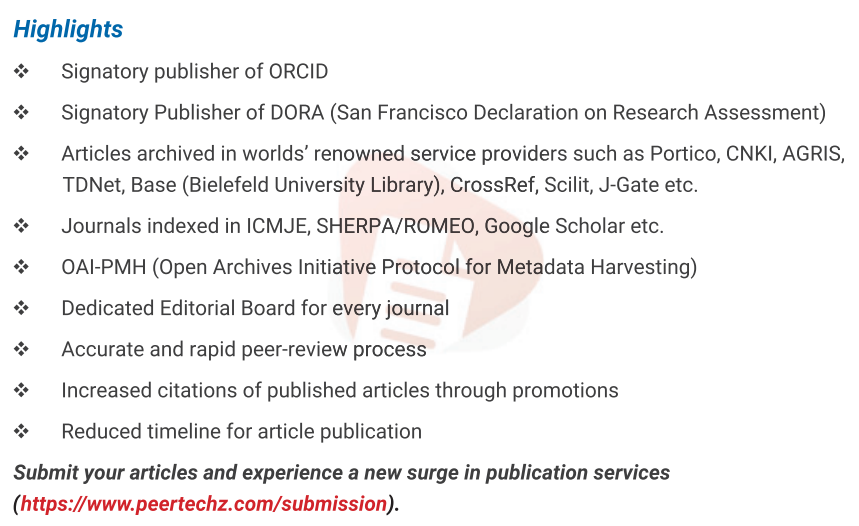

Peertechz journals wishes everlasting success in your every endeavours.

Copyright: ๑ 2020 Chauhan V. This is an open-access article distributed under the terms of the Creative Commons Attribution License, which permits unrestricted use, distribution, and r eproduction in any medium, provided the original author and source are credited. 